\title{
ПРИМЕНЕНИЕ МЕТОДА СОПРОТИВЛЕНИЙ ДЛЯ ВЫЯВЛЕНИЯ ЗОН ТРЕЩИНОВАТОСТИ В СЕВЕРО-ВОСТОЧНОЙ ЭСТОНИИ
}

На изучение зон трещиноватости ордовикской карбонатной толщи в Северо-Восточной Эстонии продолжительное время сосредоточено особое внимание, так как они вызывают большие трудности при разработке месторождений горючих сланцев. Систематические комплексные исследования зон трещиноватости проводились в 1946-1970 гг. М. С. Газизовым (1971) или под его руководством, в 1953-1955 гг. Западным геофизическим трестом (Кабанов, 1960), в 1959-1971 гг. Институтом геологии АН ЭССР (ИГ АН ЭССР) под руководством Ю. Х. Хейнсалу (Хейнсалу, Андра, 1975) и начиная с 1958 г. Управлением геологии ЭССР (УГ ЭССР).

М. С. Газизов (1971) называет закарстованные зоны трещиноватости преимущественно тектонической природы карстовыми нарушениями и выделяет в их поперечном разрезе (в пределах промышленной пачки горючих сланцев) следующие структурные зоны (от периферии к центру): 1) трещиноватости, 2) дробления, 3) остаточные глины, средняя ширина которых равна соответственно 15, 11 и 16 м (общая ширина в среднем 67 м). Последние две являются опасными для ведения подземных работ. От периферии к центру отмечается также тенденция увеличения раздробленности, обводненности и степени доломитизации карбонатных пород.

Зона остаточной глины (карста) в горных выработках отчетливо выделяется визуально, зато внешние границы зон дробления и трещиноватости обычно нечеткие. Результаты подземного симметричного электропрофилирования показали, что величина понижения значения кажущегося электрического сопротивления $\left(\varrho_{k}\right)$ тесно связана с интенсивностью трещиноватости (Андра и др., 1967). Вследствие того кривые Qk позволяют уточнить местоположение границ зон дробления, а также общую ширину зон трещиноватости.

Ю. Х. Хейнсалу (Хейнсалу, Андра, 1975) подробно описал небольшие (амплитудой до 3 м) нарушения в залегании пород (сбросы, флексуры, поднятия, прогибы), нанболее часто встречающиеся в зонах трещиноватости Северо-Восточной Эстонии.

Геоэлектрической моделью зон трещиноватости является вертикальный или крутопадающий пласт пониженного сопротивления, причем изменение электрического сопротивления в горизонтальном направлении можно условно считать следующим: $\varrho_{1}>\varrho_{2}>\varrho_{3}<\varrho_{2}<\varrho_{1}$. При этом слою $\varrho_{1}$ соответствуют вмещающие породы с фоновой трещиноватостью, слою $\varrho_{2}$ - периферийные части зон с повышенной трещиноватостью и слою $\varrho_{3}$ - раздробленные, сильно обводненные и закарстованные породы центральной части зон. Величина $\varrho_{2}$ и $\varrho_{3}$ зависит в основном от следующих факторов (Огильви, 1962): 1) от общего объема трещин и каверн по отношению к изучаемому объему горных пород, 2) от распределения и ориентации трещин, 3) от характера вещества, заполняющего трещины и каверны (воздух, вода, глина, песок и т. д.) 
Х. Р. Андра (Хейнсалу, Андра, 1975) обобщил результаты опытных геофизических исследований ИГ АН ЭССР 1951-1971 гг. и рекомендует для выявления зон трещиноватости метод дипольного электропрофилирования (ДП). При производственных работах применяли в 1952 г. симметричное электропрофилирование (СП), в 1953-1962 гг. - комбинированное электропрофилирование (КП) и начиная с 1963 г. - наиболее экономное ДП. К концу 1980 г. электропрофилированием всего было исследовано 2900 км² $^{2}$ площади и выделено около 700 аномальных зон, азимут простирания которых колеблется в основном от 0 до $110^{\circ}$. Подавляющее большинство из них имеет северо-восточное направление.

Достоверность истолковывания характера геологических объектов, вызвавших аномалии, оценивается в сравнении с геологическими данными. В 1980 г. В. Я. Данченко провел такое сравнение по выделенным аномальным зонам для вскрытых горными выработками ПО «Эстонсланец» закарстованных зон трещиноватости (табл. 1) и для контрольных скважин УГ ЭССР. В результате этих сопоставлений (неопубликованный отчет УГ ЭССР 1980 г.) он обратил внимание на следующие закономерности: 1) чем больше интенсивность аномалий и протяженность аномальных зон, тем больше подтверждаемость предположения, что они обусловлены закарстованными зонами трещиноватости, 2) чем больше глубина залегания промышленной пачки горючих сланцев, тем меньше достоверность истолковывания выявленных аномальных зон как зон трещиноватости, закарстованных на уровне промышленной пачки.

Таблица 1

\section{Сопоставление результатов электропрофилирования с данными горных работ}

\begin{tabular}{|c|c|c|c|c|c|c|c|}
\hline \multirow{4}{*}{$\begin{array}{c}\text { Название } \\
\text { карьеров и шахт }\end{array}$} & \multicolumn{6}{|c|}{ Количество аномальных зон } & \multirow{4}{*}{ 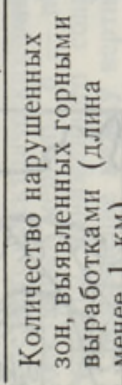 } \\
\hline & \multicolumn{3}{|c|}{$\begin{array}{c}\text { выявленных } \\
\text { электропрофилированием }\end{array}$} & \multicolumn{3}{|c|}{$\begin{array}{c}\text { подтвержденных } \\
\text { горными выработками }\end{array}$} & \\
\hline & \multicolumn{2}{|c|}{ длина, км } & \multirow{2}{*}{ всего } & \multicolumn{2}{|c|}{ длина, км } & \multirow{2}{*}{ вcero } & \\
\hline & до 1 & более 1 & & до 1 & более 1 & & \\
\hline
\end{tabular}

$\begin{array}{lrrrrrrr}\text { Октябрьский } & 2 & 11 & 13 & 1 & 10 & 11 & - \\ \text { Вийвиконд } & 3 & 1 & 4 & 1 & 1 & 2 & 1 \\ \text { Сиргала } & 3 & 5 & 8 & 3 & 5 & 8 & 1 \\ \text { Нарвский } & 5 & 5 & 10 & 5 & 5 & 10 & 1 \\ \text { Кохтла } & - & 1 & 1 & - & 1 & 1 & - \\ \text { Сомпа } & - & 5 & 5 & - & 5 & 5 & 4 \\ \text { Таммику } & 2 & 14 & 16 & - & 14 & 14 & 1 \\ \text { Ахтме } & - & 6 & 6 & - & 6 & 6 & - \\ \text { Виру } & 3 & 7 & 10 & 1 & 6 & 7 & 1 \\ \text { Эстония } & 4 & 4 & 8 & 1 & 2 & 3 & 6 \\ \text { Всего } & 22 & 59 & 81 & 12 & 55 & 67 & 15\end{array}$

Пр и ме ч ан и е. Сопоставление провел В. Я. Данченко в 1980 г. 
Как и следовало ожидать, данные табл. 1 показывают, что не все аномальные зоны обусловлены закарстованными зонами трещиноватости и не все закарстованные зоны отражаются на кривых Qk. Но с другой стороны эти данные убедительно доказывают высокую геологическую эффективность электропрофилирования в отношении выявления и прослеживания закарстованных зон трещиноватости: все закарстованные зоны протяженностью более 1 км проявлялись на кривых $\varrho_{k}$, более $90 \%$ протяженных аномальных зон оказались искомыми объектами и лишь наименее опасные для ведения горных работ слабые короткие закарстованные зоны выявлялись неуверенно (достоверностью около $50 \%$ ).

Теоретические основы электропрофилирования и многие полезные примеры его применения в различных условиях приведены в работах И. М. Блоха $(1957,1962)$. Ниже будут рассмотрены некоторые практические вопросы электроразведки с целью выявления зон трещиноватости в условиях Северо-Восточной Эстонии.

Северо-Восточная Эстония подразделяется на четыре геоэлектрических района (рис. 1), типичные разрезы и кривые электропрофилирования которых показаны на рис. 2.

Район А характеризуется сильно изменчивым электрическим сопротивлением (100-1000 Ом·м) карбонатных пород небольшой мощности (до $40 \mathrm{~m}$ ). Среднее сопротивление карбонатной толщи колеблется от 500 до 900 Ом -м. В районе Б под четвертичными отложениями залегают в основном глинистые карбонатные породы среднего ордовика мощностью 15-60 м и сопротивлением 100-400 Ом·м (обычно 200-300 Ом · м). Общая мощность карбонатной толщи 40-85 м, а среднее сопротивление ее - 350-400 Ом · м. К данному району отнесена и небольшая площадь распространения разнообразных среднедевонских пород, электрическое сопротивление которых слабоизучено. В районе В верхней части разреза карбонатных пород мощностью до 40 м характерно довольно высокое сопротивление - 800-1000 Ом·м. Общая мощность карбонатной толщи здесь 85-125 м, среднее сопротивление - 400-550 Ом·м. В районе

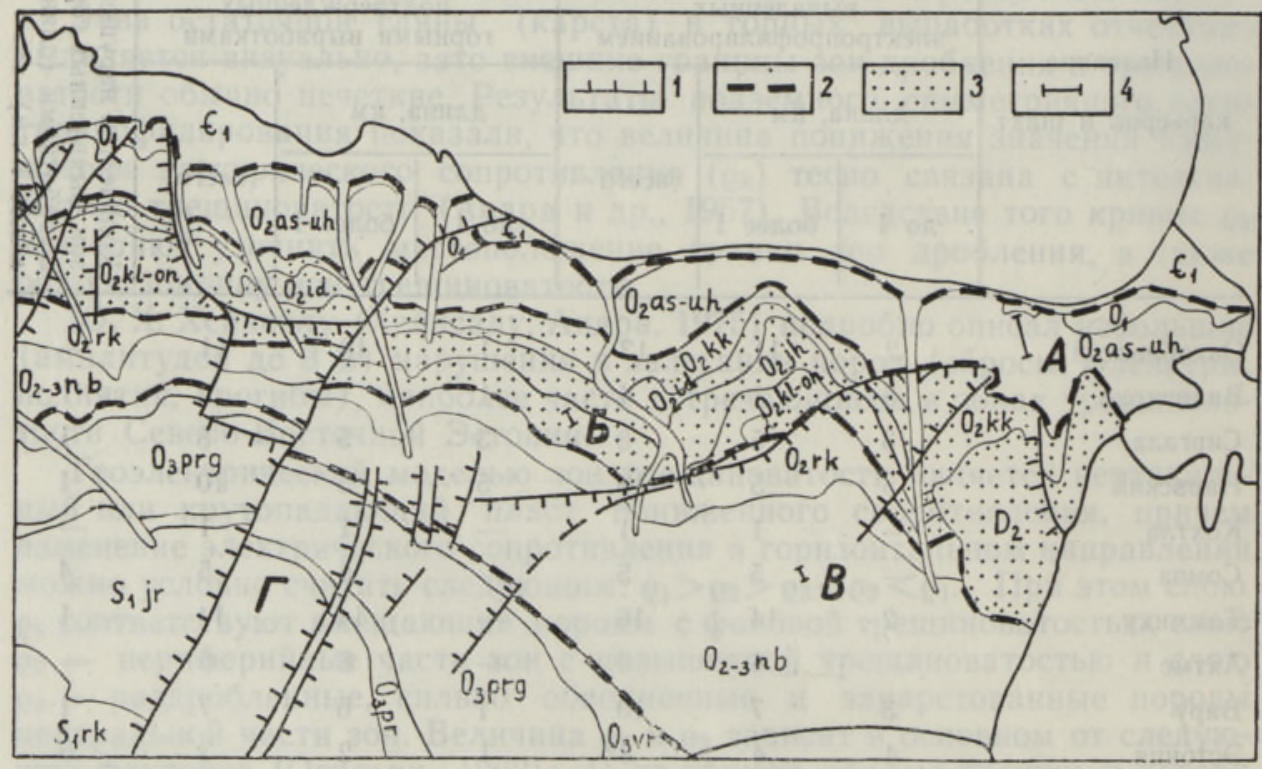

Рис. 1. Схема геоэлектрического районирования Северо-Восточной Эстонии. 1 - флексуры; 2 - границы районов А, Б, В и Г; 3 - площадь района Б; 4 - линии геологогеофизических разрезов (см. рис. 2). 


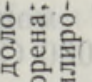

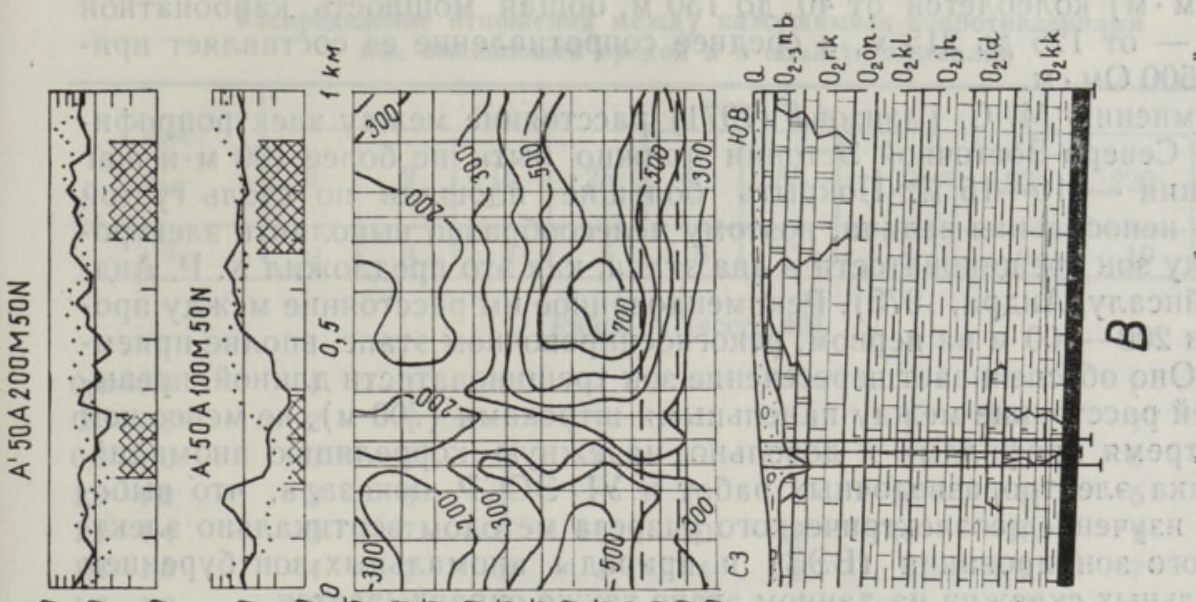
$=\frac{\nabla}{8}$ ड़े 前 1 के 炡 똘

폴 吅 \# 呵 릉ํำ 동ㅎㅀ క० 10

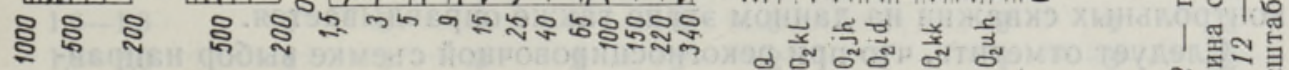

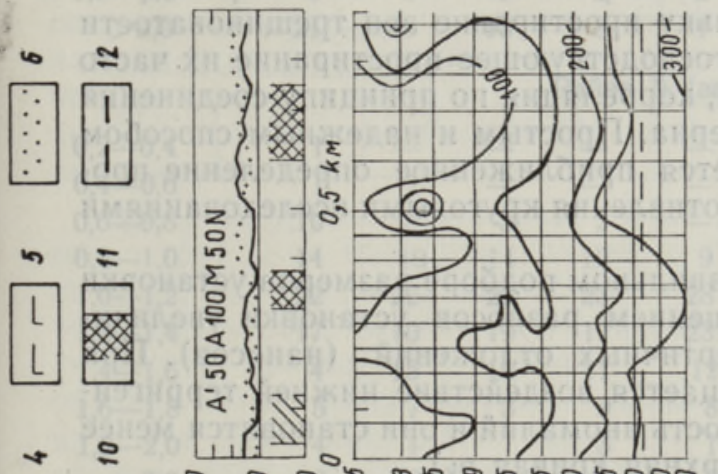

月

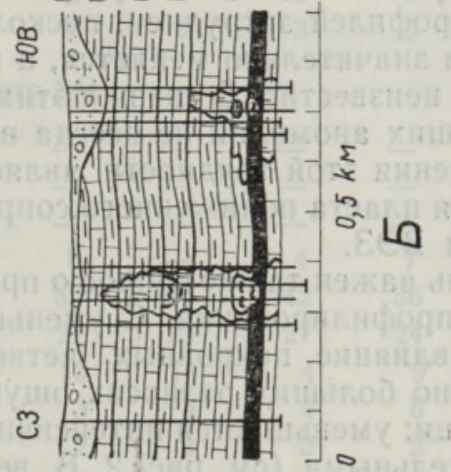

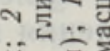

菏文

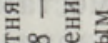

证。

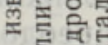

1 물

ஸे

in $5=$

$<$ 过

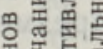

일을

०1 100

인

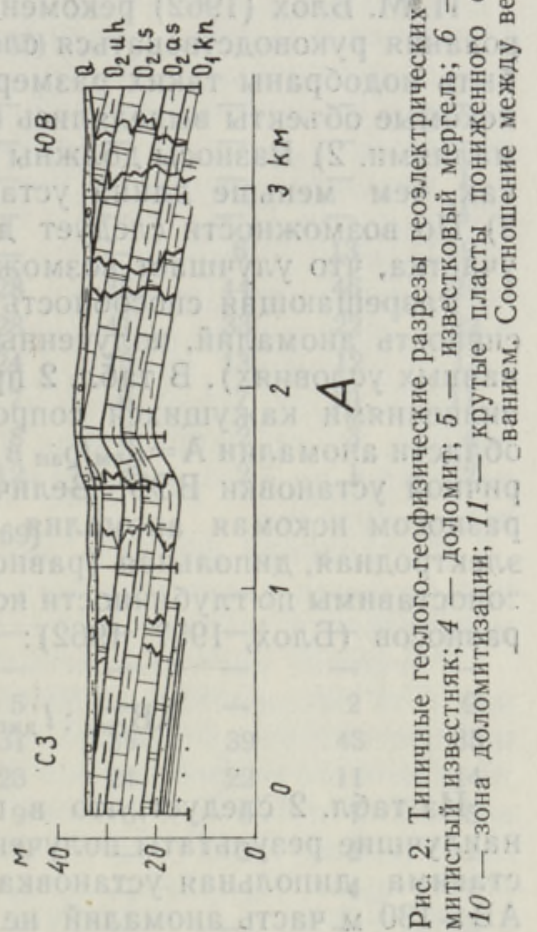


$\Gamma$ мощность карбонатных пород высокого сопротивления (7001000 Ом - м) колеблется от 40 до 130 м, общая мощность карбонатной толщи - от 125 до 215 м, а среднее сопротивление ее составляет примерно $600 \mathrm{Oм} \cdot \mathrm{m}$.

По мнению М. С. Газизова (1971) расстояние между электропрофилями в Северо-Восточной Эстонии должно быть не более 100 м и шаг измерения - 10-15 м. Покрыть большие площади по столь густой сети - непосильная задача, поэтому целесообразно выполнить электроразведку зон трещиноватости в два этапа, как это предложил Х. Р. Андра (Хейнсалу, Андра, 1975). Рекомендованное им расстояние между профилями 200-300 м на первом, рекогносцировочном этапе, вполне приемлемое. Оно обеспечивает пересечение зон трещиноватости длиной, превышающей расстояние между панельными штреками $(700$ м), не менее чем двумя-тремя профилями и довольно надежную корреляцию аномалий. Практика электроразведочных работ в УГ ӘССР показала, что выборочное изучение геоэлектрического разреза методом вертикально электрического зондирования (ВЭЗ) и природы аномальных зон бурением контрольных скважин на данном этапе также оправдывается.

Следует отметить, что при рекогносцировочной съемке выбор направления профилей затруднен, поскольку простирание зон трещиноватости местами значительно меняется, а господствующее простирание их часто заранее неизвестно. В связи с этим, корреляция по принципу соединения ближайших аномалий не всегда верна. Простым и надежным способом преодоления этой трудности является приближенное определение простирания пласта пониженного сопротивления круговыми исследованиямі методом ВЭЗ.

Очень важен также вопрос о правильном подборе размеров установки электропрофилирования. С уменьшением разносов установки увеличивается влияние покровных четвертичных отложений (наносов). При чрезмерно больших разносах ощущается воздействие нижней терригенной толщи: уменьшается интенсивность аномалий и они становятся менее выразительными (см. рис. 2, В, верхняя кривая $\mathrm{Qk}_{\mathrm{k}}$ ).

И. М. Блох (1962) рекомендует при установлении разносов профилирования руководствоваться следующими положениями: 1) Они должны быть подобраны таких размеров, чтобы на протяжении всего участка искомые объекты выделялись на графиках достаточно отчетливыми аномалиями. 2) Разносы должны быть по возможности минимальными, так как, чем меньше длина установки, тем выше ее производительность. 3) По возможности следует добиться одинаковых разносов для всего участка, что улучшает возможности корреляции аномалий по площади.

Разрешающая способность установки тем выше, чем больше интенсивность аномалий, полученных электропрофилированием (при прочих равных условиях). В табл. 2 приведено распределение отношения между значениями кажущихся сопротивлений над вмещающей средой и в

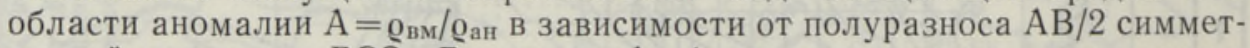
ричной установки ВЭЗ. Величина $\mathrm{A} \leqslant 1$ указывает на то, что данным разносом искомая аномалия не выявляется. Симметричная четырехэлектродная, дипольная (равнодипольная) и трехэлектродная установки гопоставимы по глубинности исследования при следующих соотношениях разносов (Блох, 1957, 1962):

$$
\mathrm{AB}_{\text {сим }}: l_{\text {дип }}: l_{\text {трехэл }}=1: \frac{2}{3}: \frac{1}{2} .
$$

Из табл. 2 следует, что в геоэлектрическом районе А методом ВЭЗ наилучшие результаты получены с разносом $\mathrm{AB}=80 \mathrm{~m}$, с которым сопоставима дипольная установка при $l=53$ м. С разносами $\mathrm{AB} \leqslant 50$ м и $\mathrm{AB} \geqslant 130$ м часть аномалий не выявлялась. В районе Б положительные 
Таблица 2

Распределение отношения между кажущимися сопротивлениями

над вмещающей средой и в области аномалии

\begin{tabular}{|c|c|c|c|c|c|c|c|c|c|c|}
\hline \multirow{2}{*}{$\frac{\varrho_{\mathrm{BM}}}{\varrho_{\mathrm{aH}}}$} & \multicolumn{10}{|c|}{$\mathrm{AB} / 2, \mathrm{M}$} \\
\hline & 5 & 9 & 15 & 25 & 40 & 65 & 100 & 150 & 220 & 340 \\
\hline 1 & 2 & 3 & 4 & 5 & 6 & 7 & 8 & 9 & 10 & 11 \\
\hline
\end{tabular}

Район А (всего 40)

\begin{tabular}{|c|c|c|c|c|c|c|c|c|c|c|}
\hline $0,4-0,6$ & 1 & 1 & 1 & - & - & - & - & - & 1 & 1 \\
\hline $0,6-0,8$ & 2 & 1 & 1 & 1 & - & - & 1 & 1 & 1 & 4 \\
\hline $0,8-1,0$ & 3 & 1 & 3 & 2 & - & 3 & 2 & 5 & 5 & 6 \\
\hline $1,0-1,2$ & 3 & 6 & 7 & 6 & 12 & 9 & 10 & 8 & 5 & 7 \\
\hline $1,2-1,4$ & 3 & 7 & 6 & 11 & 10 & 10 & 10 & 10 & 9 & 3 \\
\hline $1,4-1,6$ & 4 & 3 & 3 & 4 & 4 & 6 & 4 & 7 & 7 & 12 \\
\hline $1,6-1,8$ & 2 & 3 & 3 & 6 & 5 & 3 & 3 & 2 & 4 & 3 \\
\hline $1,8-2,0$ & 1 & 2 & 3 & 2 & 2 & 2 & 4 & 4 & 3 & 2 \\
\hline$>2,0$ & 21 & 16 & 13 & 8 & 7 & 7 & 6 & 3 & 5 & 2 \\
\hline
\end{tabular}

Район Б (всего 84)

$\begin{array}{rrrrrrrrrrr}0,2-0,4 & 1 & - & - & - & - & - & - & - & - & - \\ 0,4-0,6 & 1 & 1 & - & - & - & - & - & - & - & - \\ 0,6-0,8 & 10 & 3 & 5 & 2 & - & - & - & - & - & - \\ 0,8-1,0 & 14 & 19 & 14 & 12 & 9 & 5 & - & 4 & 7 & 9 \\ 1,0-1,2 & 22 & 22 & 22 & 23 & 28 & 32 & 41 & 42 & 36 & 30 \\ 1,2-1,4 & 17 & 10 & 19 & 17 & 23 & 27 & 23 & 27 & 24 & 16 \\ 1,4-1,6 & 4 & 15 & 10 & 11 & 12 & 13 & 14 & 4 & 9 & 20 \\ 1,6-1,8 & 5 & 7 & 3 & 9 & 8 & 3 & 4 & 4 & 5 & 6 \\ 1,8-2,0 & 4 & 1 & 7 & 3 & 1 & 2 & 1 & 3 & 2 & 3 \\ >2,0 & 6 & 5 & 4 & 7 & 3 & 2 & 1 & - & 1 & -\end{array}$

Район В (всего 107)

$\begin{array}{rrrrrrrrrrr}<0,2 & 1 & 1 & - & - & - & - & - & - & - & - \\ 0,2-0,4 & - & 1 & 1 & - & - & - & - & - & - & - \\ 0,4-0,6 & 8 & 4 & 1 & - & - & - & - & - & - & 1 \\ 0,6-0,8 & 11 & 7 & 6 & 3 & - & - & - & - & - & 11 \\ 0,8-1,0 & 19 & 20 & 13 & 8 & 4 & - & - & 6 & 13 & 19 \\ 1,0-1,2 & 18 & 16 & 21 & 23 & 25 & 28 & 35 & 44 & 46 & 24 \\ 1,2-1,4 & 9 & 13 & 18 & 23 & 22 & 28 & 41 & 33 & 22 & 22 \\ 1,4-1,6 & 12 & 9 & 12 & 11 & 19 & 24 & 15 & 13 & 12 & 13 \\ 1,6-1,8 & 6 & 7 & 8 & 9 & 12 & 7 & 6 & 7 & 10 & 11 \\ 1,8-2,0 & 2 & 3 & 6 & 10 & 9 & 8 & 6 & 2 & 3 & 4 \\ >2,0 & 21 & 26 & 21 & 20 & 16 & 12 & 4 & 2 & 1 & 2\end{array}$

Район Г (всего 69)

$\begin{array}{rrrrrrrrrrr}0,2-0,4 & 2 & 1 & - & - & - & - & - & - & - & - \\ 0,4-0,6 & 3 & 2 & 1 & - & - & - & - & - & - & - \\ 0,6-0,8 & 11 & 9 & 7 & 7 & 2 & - & - & - & - & - \\ 0,8-1,0 & 16 & 16 & 14 & 13 & 8 & 5 & - & - & 2 & 9 \\ 1,0-1,2 & 14 & 12 & 18 & 20 & 31 & 31 & 39 & 39 & 43 & 35 \\ 1,2-1,4 & 11 & 16 & 16 & 21 & 20 & 23 & 24 & 22 & 11 & 14 \\ 1,4-1,6 & 9 & 7 & 8 & 5 & 4 & 9 & 6 & 6 & 7 & 5 \\ 1,6-1,8 & 2 & 6 & 5 & 3 & 4 & 1 & - & 3 & 2 & 2 \\ 1,8-2,0 & 1 & - & - & - & - & - & - & - & 4 & 1 \\ >2,0 & - & - & - & - & - & - & - & - & - & 3\end{array}$


результаты давала установка с $\mathrm{AB}=200$ м $\left(l_{\text {дип }}=133\right.$ м $)$. В районе В хорошие результаты получены разносами $\mathrm{AB}=130-200$ м $\left(l_{\text {дип }}=87-\right.$ $133 \mathrm{м})$, а в районе $\Gamma-\mathrm{AB}=200-300$ м $\left(l_{\text {дип }}=133-200 \mathrm{~m}\right)$. Сравнивая по применимости различные разносы (табл. 3), легко заметить, что нет общего разноса, пригодного на всей территории Северо-Восточной Эстонии. Общий разнос имеется лишь для трех районов. Таким образом, учитывая, что для удобства полевых работ разносы установок следует выбирать кратными шагу наблюдений, в районах Б, В, Г оптимальной является дипольная установка с разносом $l=140-150 \mathrm{~m}$, а в районе $\mathrm{A}-l=50-60$ м. Для улучшения возможности корреляции аномалий на стыке соседних районов, в южной части района А желательно выполнять рекогносцировочное ДП на двух разносах: $l_{1}=50$ м (основной) и $l_{2}=150$ м (вспомогательный).

Таблица 3

Оптимальные разносы электропрофилирования

в Северо-Восточной Эстонии (по данным ВЭЗ)

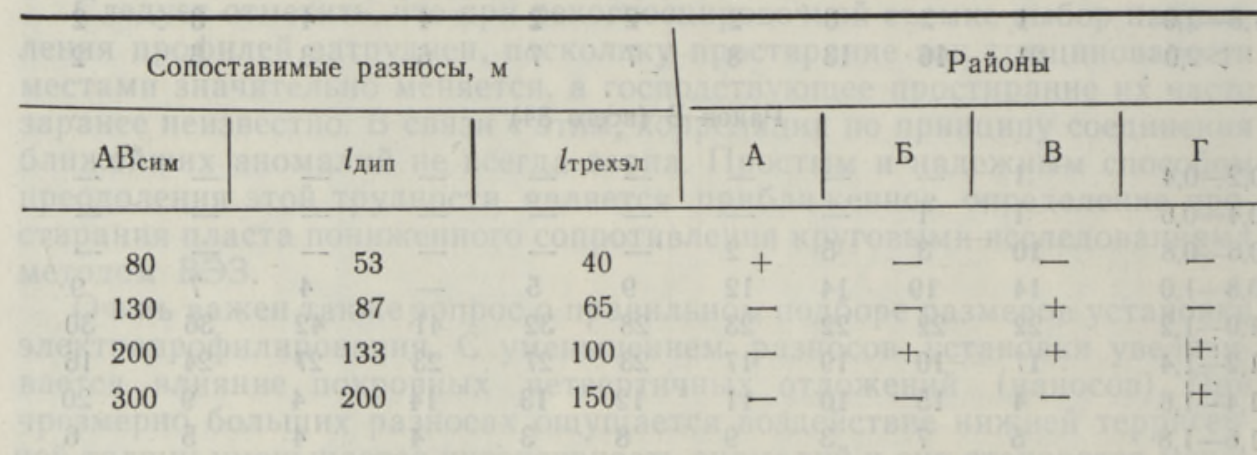

Результаты электропрофилирования на первом этапе дают представление о густоте, распределении и простираниях аномальных зон на изучаемой площади. Но этого недостаточно для рационального планирования и ведения горных работ. Поэтому на втором этапе исследований потребуется детальная съемка на небольших участках с целью уточнения местонахождения, размеров и характера предполагаемых зон трещиноватости. При этом нельзя забывать о подчеркнутой М. С. Газизовым (1971) необходимости сочетания геолого-гидрогеологических методов с геофизическими (особенно бурения контрольных скважин на аномалиях), опережения панельных штреков по отношению к добычным блокам, и уточнения размеров и строения структурных зон в них. Хотя часть вопросов методики электропрофилирования на втором этапе, например, выбор направления профилей и оптимальных разносов, легко решаются на основании результатов первого этапа, возникает и ряд новых проблем.

Постараемся пояснить возможности и ограничения электроразведки при решении задач изучения закарстованных зон трещиноватости применительно к требованиям сланцедобывающей промышленности.

Уточнение местоположения аномальных зон добивается путем сгущения сети наблюдений до $50 \times 5$ м. Естественно, что с уменьшением шага наблюдений увеличивается и точность определения контакта пласта пониженного сопротивления. Но определение мощности (щирины) пласта возможно лишь при наличии на графиках электропрофилирования характерных точек. Часто они выражены весьма слабо или совсем отсутствуют. Например, на графиках КП 1953-1955 гг. (выполненного в районе Б по сети $100 \times 20$ м) многие аномалии были сильно сглажен- 
ными, из-за чего по 776 аномалиям из 1530 (51\%) определение мощности пласта не представлялось возможным. Чтобы исчерпывающим образом провести количественную интерпретацию, необходимо стремиться к увеличению интенсивности и отчетливости аномалий. Выразительность аномалии зависит, кроме соотношения удельных электрических сопротивлений пород, от ряда факторов (направление профилей, размеры установок, мощность и характер наносов), влияние которых подробно рассмотрено в работах И. М. Блоха $(1957,1962,1966)$. При детальной съемке необходимо соблюдать изложенные в этих работах положения методики ДП, позволяющие наиболее эффективно реализовать его картировочные возможности.

Сложнее установить характер геологических объектов, вызвавших аномалии. Горняков больше всего интересует ответ на вопрос о наличии или отсутствии карста в зонах трещиноватости на уровне промышленной пачки горючих сланцев и о ширине и степени его проявления. В 1953 1954 гг. выделенные по графикам КП аномальные зоны были подразделены по интенсивности на три группы, якобы связанных со степенью закарстованности зон. Однако, впоследствии геологические данные показали, что связи между интенсивностью проявления аномалий @k и степенью закарстования промышленного пласта горючих сланцев не наблюдается. Это вполне понятно, так как кривые $\varrho_{k}$ отражают суммарное влияние всех неоднородностей пород в разрезе, а мощность промышленного пласта составляет небольшую долю общей мощности карбонатных пород.

Вследствие увеличения расстояния между питающими электродами возрастает доля тока, проникающего глубже в землю и при наблюдениях длинные разносы дадут больше сведений о более глубоких геологических условиях, чем короткие. Благодаря этому, на разрезах $0_{k}$, составленных по данным ВЭЗ, местами удается выделить аномалии, явно обусловленные поверхностными неоднородностями и не представляющие интереса для сланцедобывающей промышленности. Исходя из этого, на втором этапе исследований методом ВЭЗ следует изучать все выделенные аномальные зоны по крайней мере на одном из профилей детальной съемки и на всех линиях планируемых панельных штреков.

Неотъемлемой частью комплексного изучения закарстованных зон трещиноватости является бурение контрольных скважин на аномалиях с целью выяснения роли разных факторов, вызывающих аномалии (литология, тектоника, закарстованность, обводненность, минерализация вод, изменение мощности рыхлых отложений и др.). С помощью буровых скважин следует проверить все аномалии, изученные методом ВЭЗ, за исключением тех, которые по данным ВЭЗ выделены как приповерхностные. В результате проверки обычно удается установить связь подавляющего большинства аномальных зон с закарстованными зонами трещиноватости, чаще всего по косвенным признакам (доломитизация и повышенная кавернозность пород, низкий выход керна), реже по прямым данным развития карста. Детализированный план этих аномальных зон служит надежной основой для проектирования горных предприятий и перспективного планирования горных работ.

Ширина и строение закарстованных зон трещиноватости окончательно устанавливаются способом тщательной визуальной геологической документации их по подготовительным (опережающим) горным выработкам, сопровождаемой подземным электропрофилированием, определением степени доломитизации и физических, механических и фильтрационных свойств пород. Эти данные дают возможность оценить степень опасности зон в пространстве между панельными и сборными штреками и оперативно планировать горные работы.

Итак, картировочные возможности электроразведки в Северо-Восточ- 
ной Әстонии ограничиваются малой интенсивностью и выразительностью многих аномалий, что затрудняет проведение количественной интерпретации и определение природы некоторых явлений, которые в качестве составляющей входят в результаты измерений. Они ограничиваются также различными помехами, например блуждающими токами индустриального происхождения, создающими т. н. ложные аномалии (Хейнсалу, Андра, 1975). Опыт изучения закарстованных зон трещиноватости в условиях Прибалтийского сланцевого бассейна показывает, что для удовлетворительного решения основных горногеологических задач необходимо применение комплексных (геологических и геофизических) методов изучения (Газизов, 1971). Однако это не умаляет значение результатов электроразведки. ДП с точки зрения экономических факторов является наиболее эффективным методом выявления, прослеживания и оконтуривания закарстованных зон трещиноватости с поверхности земли. Результаты электроразведки позволяют выбрать рациональное расположение буровых скважин и значительно сократить расходы по геологоразведочным работам. Местоположение зон трещиноватости может быть установлено также методами сейсморазведки (Хейнсалу, Андра, 1975) и инфракрасной съемки (Вишневский и др., 1978), однако по экономическим показателям эти методы намного уступают электроразведке. Сейсмоакустический метод (Газизов, Юргенфельдт, 1981; Газизов, Исаев, 1981) является перспективным для эксплуатационного прогнозирования карста из подземных горных выработок (впереди забоев панельных штреков и в пределах выемочных столбов).

В итоге можно рекомендовать комплексное изучение зон трещиноватости в условиях Северо-Восточной Эстонии по следующей схеме (учитывая также предложения М. С. Газизова и Х. Р. Андра). Первый этап - выявление характера распространения зон для районирования территории по горногеологическим условиям. Площадная съемка ДП с разносами $l=150$ м в области распространения горючих сланцев, $l_{1}=$ $=50$ м и $l_{2}=150$ м севернее этой области; расстояние между профилями 200-300 м, шаг 25 м. Проверка корреляции аномалий круговыми ВЭ3. Выборочное изучение выделенных аномальных зон профилями ВЭЗ и контрольных скважин. Второй этап - уточнение местоположения и строения закарстованных зон трещиноватости для проектирования горных предприятий и планирования горных работ. Детальная съемка ДП с принятием мер для увеличения выразительности аномалий. Выбор разносов и направления профилей на основе результатов первого этапа. Расстояние между профилями 50-100 м, шаг 5-10 м. Изучение всех аномальных $30 н$ профилями ВЭЗ, контрольное бурение на профилях ВЭЗ (за исключением тех аномалий, которые по данным ВЭЗ признаны приповерхностными). Тщательное описание зон в подготовительных горных выработках, сопровождаемое определением степени доломитизации и физических, механических и фильтрационных свойств пород. СП в тех же выработках для уточнения ширины зон, разнос $\mathrm{AB}=2$ м и шаг $0,5-$ $1 \mathrm{M}$.

\section{Л И Т Е РА Т У РА}

Андра Х., Хейнсалу Ю., Юргенфельдт Г. О применении подземного электрического профилирования для изучения закарстованных зон тектонических нарушений. Изв. АН ЭССР. Хим. Геол., 1967, 16, № 2, 126-130.

Блох И. М. Дипольное электропрофилирование. М., 1957.

Блох И. М. Электропрофилирование методом сопротивлений. М., 1962.

Блох Н. М. Возможности и ограничения дипольного электропрофилирования при решении задач геологического картирования, - Разведочная геофизика, 1966, вып. $17,62-66$. 
Вишневский П., Вассерман В., Бареев Н., Гуревич В., Хейнсалу Ю., Вахер Р., Глухов А. Инфракрасная съемка на участке Виру-Нигула Эстонской ССР. - Изв. АН ЭССР. Геол., 1978, 27, № 4, 148-150.

Газизов М. С. Карст и его влияние на горные работы. М., 1971.

Газизов М. С., Юргенфельдт Г. Ю. Геологические основы прогнозирования карстовых нарушений геофизическими методами на сланцевых шахтах. - В кн.: Вопросы геолого-маркшейдерской службы на сланцевых шахтах. Таллин, 1981, $72-86$.

Газизов М. С., Нсаев Ю. С. Опробование методов сейсморазведки для прогнозирования карстовых нарушений из подземных выработок сланцевых шахт. - В кн.: Вопросы геолого-маркшейдерской службы на сланцевых шахтах. Таллин, 1981, 86-96.

Кабанов О. М. Опыт применения комбинированного профилирования для выявления глубинного карста на Эстонском месторождении горючих сланцев. - Разведка и охрана недр, 1960, № 3, 55-57.

Огильви А. А. Геофизические методы исследований. М., 1962.

Хейнсалу Ю. Х., Андра Х. Р. Трещиноватость в зоне сланцевых шахт Эстонии и геофизические методы ее исследования. Таллин, 1975.

\author{
Институт геологии \\ Академии наук Эстонской ССР
}

Поступила в редакцию

29/IV 1985

\title{
R. VAHER
}

\section{ELEKTRITAKISTUSE MEETODI KASUTAMINE LOHEVOONDITE ASUKOHTADE KINDLAKSMÄÄRAMISEKS KIRDE-EESTIS}

Aastail 1953-1962 kasutati põlevkivi kaevandamist raskendavate karstunud lōhevööndite avastamiseks kombineeritud elektroprofileerimist. Hiljem on saadud samaväärseid tulemusi ökonøomsema dipoolse elektroprofileerimisega. Elektrosondeerimine vōimaldab elimineerida neid anomaaliaid, mis on tingitud pinnalähedastest struktuuridest. Olejäänud anomaaliate geoloogiliste põhjuste selgitamiseks peab kasutama kontrollpuurimist.

\section{R. VAHER}

\section{APPLICATION OF THE RESISTIVITY METHOD FOR LOCATING FRACTURE ZONES IN NORTH-EASTERN ESTONIA}

Successful earth-resistivity measurements in 1953-1962 for locating fracture zones in north-eastern Estonia were made in the horizontal profiling technique with the Lögn configuration of electrodes. Later, the dipole configuration gave similar results at smaller costs. Above the Estonian oil-shale mines about $80 \%$ of the low-resistivity zones are located over the karsted fracture zones which are already in sight (Table 1). The sounding technique with Schlumberger configuration proved useful permitting under favourable field conditions the elimination of the apparent-resistivity anomalies obtained from profiling measurements over the filled depressions lying at shallow depths. In the case of the rion-eliminated anomalies one must test the buried structural features by boring. 